\title{
PROSPEK PEMANFAATAN LIMBAH PERIKANAN SEBAGAI SUMBER KOLAGEN
}

\author{
Nurhayati dan Rosmawaty Peranginangin*)
}

\begin{abstract}
ABSTRAK
Pengolahan hasil perikanan seperti pengalengan dan filet ikan biasanya memiliki produk samping berupa kepala, sirip, tulang, sisik maupun kulit ikan dalam jumlah yang melimpah. Limbah perikanan tersebut dapat diproses lebih lanjut menjadi kolagen yang bernilai ekonomis tinggi. Kolagen terdapat pada jaringan ikat dalam kulit, tendon, tulang keras, dan tulang rawan. Pelarutan protein non kolagen, mineral maupun lemak diperlukan untuk memudahkan proses ekstraksi kolagen. Umumnya proses ekstraksi kolagen dilakukan dalam suasana asam. Namun, penggunaan pepsin pada proses ekstraksi ternyata diketahui dapat meningkatkan rendemen kolagen yang diperoleh. Karakteristik kolagen dapat dilihat dari kelarutan, viskositas, suhu denaturasi, dan kandungan asam amino yang diperoleh. Saat ini, penggunaan kolagen pada industri telah meluas, khususnya pada bidang medis, pangan, dan kosmetik. Menurut data statistik, diperkirakan bahwa limbah perikanan sebesar 1,81 juta ton pertahun dihasilkan oleh perikanan tangkap. Jika rendemen kolagen berkisar antara 11-63\% maka diperkirakan dapat dihasilkan kolagen dalam jumlah yang besar, yaitu sekitar $0,20-1,14$ juta ton. Hal ini menunjukkan bahwa limbah perikanan dapat menjadi sumber kolagen yang potensial.
\end{abstract}

\section{ABSTRACT: The prospect of fishery waste as collagen source. By: Nurhayati and Rosmawaty Peranginangin}

Fisheries product processing like fish canning and filleting produces a large amount of by products such as fish heads, fins, bones, scales and skins. Fishery waste is a valuable source of collagen presenting a high economic value. Collagen could be found in connective tissues in skin, tendon, skeleton and cartilage. Dissolving non collagen protein, mineral and fat is necessary to simplify the process of collagen extraction. Generally, the extraction of collagen is conducted in acidic condition. However, the use of pepsin in extraction process may increase the yield of collagen. Characteristics of collagen are determined based on its solubility, viscosity, denaturation temperature and amino acid's content. Nowadays, collagen is widely used in industry, especially for medical, food, and cosmetic purposes. Based on the statistical data, the estimated waste from captured fishery in Indonesia is about 1.81 million tons per years. If the yield of collagen is $11-63 \%$, then collagen in a large amount, about $0.20-1.14$ million tons, could be produced. This fact shows that fishery waste is a potential source of collagen.

\section{KEYWORDS: $\quad$ fishery waste, collagen, extraction, characteristic}

\section{PENDAHULUAN}

Indonesia merupakan negara kepulauan yang memiliki potensi sumber daya perikanan yang sangat besar. Hasil perikanan tersebut tidak hanya dipasarkan dalam bentuk segar, tetapi diolah menjadi produk yang memiliki nilai tambah yang lebih tinggi. Pada proses produksinya, industri pengolahan perikanan seringkali menghasilkan limbah dalam jumlah yang melimpah. Limbah perikanan terdiri dari limbah cair dan limbah padat. Limbah cair berupa darah, lendir, dan lemak, sedangkan limbah padat berupa kepala, sirip, kulit, tulang, dan sisik. Limbah dari ikan tuna utuh mempunyai rendemen sebagai berikut: bagian daging $57,15 \%$; kulit 4,9\%; kepala 9,8\%; tulang $23,90 \%$; dan isi perut $14,25 \%$ (Peranginangin et al., 2005). Saat ini, limbah perikanan tersebut baru dimanfaatkan menjadi tepung ikan yang digunakan sebagai bahan baku utama pada pembuatan pakan ternak. Padahal limbah perikanan memiliki nilai tambah yang tinggi karena dapat digunakan sebagai bahan baku untuk pembuatan kolagen.

Kolagen merupakan protein yang terdapat pada hewan vertebrata dan invertebrata. Keberadaannya kurang lebih mencapai $30 \%$ dari seluruh protein yang terdapat di tubuh. Kolagen merupakan struktur organik pembangun tulang, gigi, sendi, otot, dan kulit. Serat kolagen memiliki daya tahan yang kuat terhadap tekanan. Kata kolagen sendiri berasal dari bahasa Yunani yang artinya bersifat lekat atau menghasilkan pelekat. Hingga kini terdapat sekitar 28 tipe kolagen yang telah diidentifikasi, yaitu tipe I sampai XXVIII

\footnotetext{
*) Peneliti pada Balai Besar Riset Pengolahan Produk dan Bioteknologi Kelautan dan Perikanan
} 
(Anon., 2009a). Tipe-tipe kolagen tesebut terdapat pada berbagai macam jaringan, antara lain: tipe I terdapat pada kebanyakan jaringan ikat, seperti tulang, kulit, tendon, dan pembuluh darah; tipe II terdapat pada kartilago dan bagian virous mata; tipe III terdapat pada pembuluh darah; tipe IV terdapat pada membran basalis semua organ; tipe $\mathrm{V}$ terdapat pada tendon, mata, dan jaringan interstisial; tipe VI terdapat pada hati, ginjal, dan perikondrium; tipe VII terdapat pada pertemuan epidermis dengan dermis; tipe VIII terdapat pada sel endotelial; tipe IX terdapat pada kartilago; tipe X terdapat pada kartilago hipertrofik dan kartilago yang dimineralkan; tipe XI terdapat pada kartilago; tipe XII terdapat pada tendon dan kolagen fibril terasosiasi; tipe XIII terdapat pada epidermis, folikel rambut, selsel pada akar kuku; tipe XIV sama seperti tipe I; tipe $\mathrm{XV}$ terdapat pada banyak jaringan, homolog dengan tipe XVIII; tipe XVI masih dalam penelitian; tipe XVII terdapat pada hemidesmosome dan kulit; tipe XVIII terdapat pada hati dan ginjal; tipe XIX terdapat pada mata, otak, testis, dan jaringan embrionik; tipe XXXVIII terdapat pada transmembran (Anon., 2009a).

Berdasarkan bentuknya, kolagen terbagi menjadi enam kelompok yaitu kolagen fibrillar, jaringan, fibrillar terasosiasi (FACIT), rangkaian mutiara, Verankerungsfibrillen, dan transmembran. Kolagen fibrillar terdiri dari kolagen tipe I, II, III, V, dan XI. Sedangkan kolagen yang membentuk jaringan yaitu kolagen tipe IV (lamina densa dari dasar membran Hemidesmosom), VIII, dan X. Kolagen fibrillar terasosiasi (FACIT) terdiri dari kolagen tipe IX, XII, XIV, dan XXII. Kolagen berbentuk rangkaian mutiara, yaitu kolagen tipe VI. Kolagen verankerungsfibrillen yaitu kolagen tipe VII, dan kolagen dengan domain transmembran yaitu kolagen tipe XIII, XVII, XXIII, dan XXV (Anon., 2009a).

Kolagen yang banyak digunakan oleh industri umumnya berasal dari sapi dan babi. Penggunaan produk yang berasal dari babi diharamkan bagi umat Islam, sementara penggunaan sapi menimbulkan kekhawatiran akan terjangkitnya beberapa penyakit seperti sapi gila (mad cow), penyakit kuku dan mulut (foot and mouth), dan Bovine Spongiform Encephalopathy (BSE). Oleh karena itu limbah perikanan dapat dijadikan alternatif sumber kolagen, sehingga diharapkan dapat memenuhi kebutuhan kolagen yang halal dan meningkatkan nilai tambah limbah perikanan. Bahan baku perikanan yang dapat digunakan untuk memproduksi kolagen yaitu kulit, sisik, dan tulang ikan. Berbagai industri di Amerika, China, dan Jepang kini telah memproduksi kolagen.

\section{KANDUNGAN KOLAGEN DALAM LIMBAH PERIKANAN}

Pada industri pengolahan perikanan seperti industri filet dan pengalengan ikan tuna, bagian tubuh ikan berupa kepala, sirip, tulang, maupun kulit merupakan produk samping yang tidak digunakan dan dikategorikan sebagai limbah. Limbah perikanan ini dapat dimanfaatkan karena banyak mengandung protein kolagen. Kolagen merupakan komponen struktural utama dari jaringan ikat putih (white connetive tissue) yang meliputi hampir $30 \%$ dari total protein pada tubuh. Kolagen terdapat di kulit, tendon, tulang keras, tulang rawan dan jaringan ikat (DeMan, 1989). Limbah pengolahan perikanan berupa kulit, tulang, dan sisik ikan dilaporkan mengandung kolagen

Tabel 1. Rendemen kolagen dari beberapa jenis ikan

\begin{tabular}{|c|c|c|}
\hline Limbah ikan & Jenis ikan & Kolagen (\%) \\
\hline \multirow[t]{6}{*}{ Kulit } & Japanese sea bass (Lateolabrax japonicus $)^{4)}$ & 51.40 \\
\hline & Chub mackerel (Scomber japonicus $)^{4)}$ & 49.80 \\
\hline & Bullhead shark (Heterodontus japonicus $)^{4)}$ & 50.10 \\
\hline & Big eye snapper (Priacanthus tayenus $)^{1}$ & 10.94 \\
\hline & Ocellate puffer fish (Takifugu rubripes $)^{3)}$ & 44.70 \\
\hline & Nile perch muda (Lates nilotikus $)^{2)}$ & 63.10 \\
\hline \multirow[t]{3}{*}{ Tulang } & Skipjack tuna (Katsuwonus pelamis $)^{4}$ ) & 42.30 \\
\hline & Japanese sea bass (Lateolabrax japonicus $)^{4)}$ & 40.70 \\
\hline & Ayu (Plecogosus altivelis $)^{4)}$ & 53.60 \\
\hline Sirip & Japanese sea bass (Lateolabrax japonicus $)^{4)}$ & 36.40 \\
\hline
\end{tabular}

Sumber: Kittiphattanabawon et al., 2005¹); Muyonga et al., 2004²);Nagai et al., 20023); Nagai \& Suzuki, 20004); 
dengan nilai rendemen yang bervariasi antara 11-63\% tergantung dari jenis ikan, bagian tubuh ikan, bahan pengekstrak, dan teknik ekstraksi kolagen (Tabel 1).

Ekstraksi kolagen dari kulit ikan kerapu lumpur (Epinephelus tauvina) yang berasal dari limbah perusahaan pengolahan filet ikan dilakukan dengan cara menghilangkan lemak dan protein nonkolagennya melalui perendaman dalam $\mathrm{NaOH} 0,1 \mathrm{~N}$. Kolagen diekstraksi menggunakan asam asetat 0,5 $\mathrm{N}$, dilanjutkan dengan purifikasi dan presipitasi dengan $\mathrm{NaCl}$ dan buffer tris-HCl. Endapan kolagen kemudian dipisahkan dengan sentrifugasi. Rendemen kolagen hasil purifikasi adalah 25,15-47,14\% (Apriantoro, 2007). Kulit ikan kerapu yang digunakan seperti Gambar 1, kolagen basah pada Gambar 2, dan kolagen yang sudah dikeringbekukan pada Gambar 3. Ekstraksi kolagen dari tulang ikan tuna hanya diperoleh rendemen 0,10\% (Lestari, 2007).

\section{EKSTRAKSI KOLAGEN IKAN}

Ekstraksi kolagen diawali dengan pembersihan limbah perikanan seperti tulang, sirip, dan kulit dari sisa-sisa daging maupun lemak yang masih menempel. Untuk memudahkan proses ekstraksi kolagen, perlu dilakukan perendaman tulang maupun kulit dalam larutan $\mathrm{NaOH}$, sehingga protein non kolagen yang larut dalam pelarut basa dapat dihilangkan. Untuk mengurangi kadar lemak, dilakukan perendaman dalam butil alkohol. Selanjutnya dilakukan proses demineralisasi dengan menggunakan ethylendiaminetetraacetic acid (EDTA). EDTA dapat mengikat mineral yang terdapat pada tulang maupun sirip dengan cara membentuk kompleks yang larut.

Umumnya kolagen larut dalam pelarut asam tetapi pada $\mathrm{pH}$ yang sangat asam kelarutan menjadi sedikit menurun (Kittiphattanabawon et al., 2005). Oleh karena itu, ekstraksi kolagen dilakukan dengan menggunakan asam lemah dengan konsentrasi rendah seperti asam asetat. Asam asetat memiliki gugus karboksil $(-\mathrm{COOH})$ yang dapat berikatan dengan gugus amina $\left(-\mathrm{NH}_{2}\right)$ dari protein kolagen sehingga memudahkan proses ekstraksi kolagen. Kolagen yang diperoleh melalui ekstraksi dengan asam dinamakan Acid Soluble Collagen (ASC).

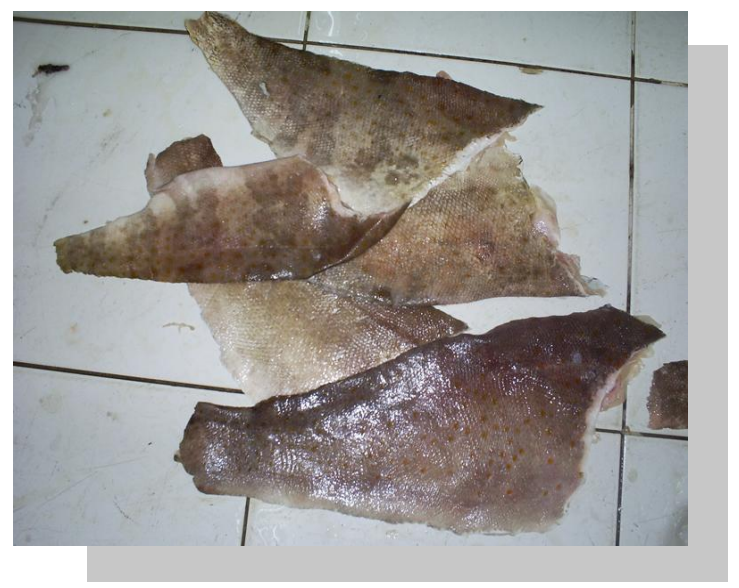

Gambar 1. Kulit ikan kerapu sebagai bahan baku kolagen.

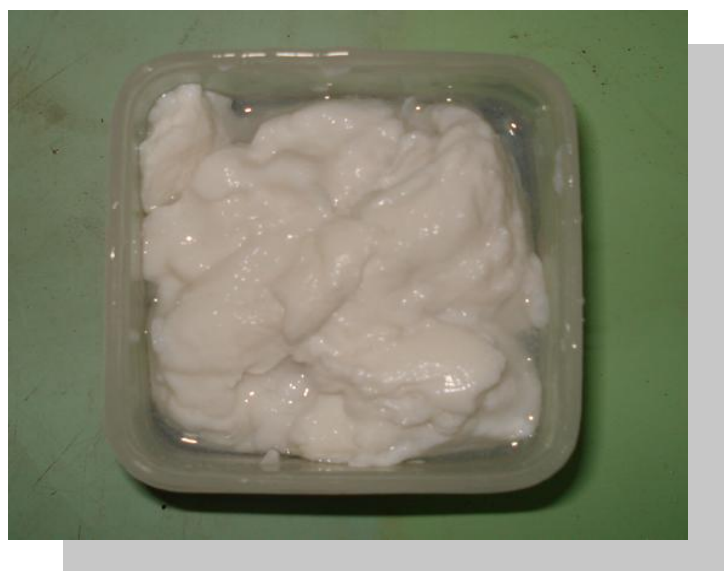

Gambar 2. Kolagen basah dari kulit ikan kerapu. 


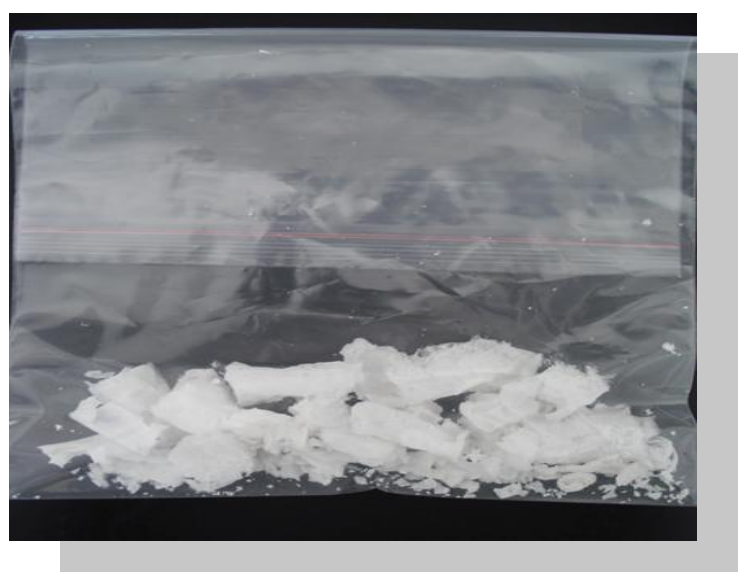

Gambar 3. Kolagen kering secara freeze dryer dari kulit ikan kerapu.

Ekstraksi kolagen menggunakan asam lemah dilaporkan menghasilkan rendemen kolagen yang rendah. Oleh karena itu digunakan bantuan enzim protease untuk membantu memecah ikatan peptida pada protein sehingga memudahkan proses ekstraksi. Enzim dapat mengkatalisis suatu reaksi kimia dengan cara menurunkan energi aktivasi reaksi sehingga proses ekstraksi menjadi lebih cepat. Ogawa et al. (2004) dan Nagai \& Suzuki (2000) menambahkan 0,1\% enzim pepsin ke dalam larutan asam asetat untuk mengekstraksi kolagen. Penambahan enzim pepsin dalam asam asetat dilakukan untuk meningkatkan kelarutan kolagen yang terkandung dalam tulang, sirip maupun kulit ikan sehingga diperoleh rendemen kolagen yang lebih tinggi. Kolagen yang dihasilkan dari proses ekstraksi ini dinamakan Pepsin Soluble Collagen (PSC).

Pengaruh penggunaan enzim pepsin dipelajari lebih lanjut oleh Nagai et al. (2002) pada kulit ikan ocellate puffer, di mana ekstraksi kolagen menggunakan asam asetat menghasilkan rendemen kolagen sebesar $10,7 \%$. Sementara itu, ekstraksi dengan penambahan pepsin dalam asam asetat menghasilkan rendemen sebesar $44,7 \%$. Penambahan enzim pepsin dapat meningkatkan kelarutan kolagen karena enzim ini merupakan enzim pemecah protein. Pepsin memecah telopeptida yang mengandung ikatan silang intermolekular tanpa merusak integritas triple helix kolagen (Jongjareonrak et al., 2005).

Pada proses ekstraksi kolagen, suhu ekstraksi juga berpengaruh terhadap rendemen kolagen yang dihasilkan. Serabut kolagen dapat mengalami penyusutan jika dipanaskan di atas suhu $60-70^{\circ} \mathrm{C}$. Proses penyusutan kolagen menyebabkan struktur kolagen pecah menjadi gelatin yang larut dalam air. Oleh karena itu, proses ekstraksi kolagen dilakukan di bawah suhu penyusutannya. Beberapa penelitian mengenai ekstraksi kolagen dengan menggunakan suhu $4^{\circ} \mathrm{C}$ dilaporkan oleh Nagai et al. (2001), Nagai \&
Suzuki (2000); Noitup et al. (2005); dan Senaratne et al. (2005). Namun, Ogawa et al. (2004) melakukan ekstraksi kolagen pada suhu $22-23^{\circ} \mathrm{C}$. Rendahnya suhu yang digunakan pada proses ekstraksi ini didasarkan oleh rendahnya suhu denaturasi kolagen.

\section{KARAKTERISTIK KOLAGEN IKAN}

Kolagen memiliki tiga rantai polipeptida yang sama panjang dan dihubungkan satu sama lain oleh berbagai ikatan silang membentuk triple helix (Gambar 4). Kolagen ikan mempunyai karakteristik sebagai berikut:

\section{Kelarutan}

Umumnya kolagen larut dalam suasana larutan yang asam. Kittiphattanabawon et al. (2005) melaporkan bahwa $\mathrm{pH}$ maksimum untuk melarutkan kolagen dari kulit adalah $\mathrm{pH} 2$, sementara kolagen tulang larut pada $\mathrm{pH}$ maksimum 5. Perbedaan $\mathrm{pH}$ maksimum pada kelarutan kolagen kulit dan tulang kemungkinan karena perbedaan sifat molekular dan konformasi pada masing-masing kolagen. Jumlah ikatan silang pada kolagen yang berasal dari kulit lebih sedikit dibandingkan dengan kolagen yang berasal dari tulang, sehingga memiliki kelarutan yang lebih tinggi. Selain $\mathrm{pH}$, suhu juga mempengaruhi kelarutan kolagen. Noitup et al. (2005) melaporkan bahwa pada suhu kamar kolagen mempunyai kelarutan yang lebih tinggi dibandingkan pada suhu $4^{\circ} \mathrm{C}$. Pada suhu kamar, energi kinetik molekul lebih tinggi daripada suhu $4^{\circ} \mathrm{C}$. Tingginya energi kinetik menyebabkan tumbukan antar molekul menjadi lebih sering terjadi sehingga proses pelarutan terjadi lebih mudah. Perbedaan larutan pengekstrak juga mempengaruhi kelarutan kolagen hasil ekstraksi. Kelarutan PSC lebih tinggi dibandingkan ASC. Tingginya kelarutan PSC disebabkan karena PSC mempunyai berat molekul yang rendah, kurangnya ikatan silang yang terjalin, 


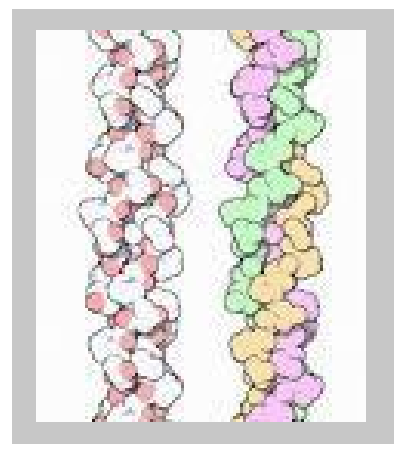

Gambar 4. Struktur kolagen (Anon., 2000).

dan kurangnya komponen gamma yang diperoleh dari hasil hidrolisis pepsin.

\section{Viskositas}

Salah satu sifat fisikokimia kolagen adalah tingginya viskositas. Tingginya viskositas tergantung dari tingginya proporsi rantai $\beta$ dan $y$ pada kolagen sehingga menghasilkan berat molekul rata-rata yang tinggi. Viskositas PSC tulang serupa dengan viskositas kolagen dari bagian lain ikan, seperti kulit. Ogawa et al. (2004) dan Kittiphattanabawon et al. (2005) melaporkan bahwa viskositas kolagen mulai mengalami penurunan pada suhu $30^{\circ} \mathrm{C}$, dan di atas suhu tersebut viskositas kolagen menjadi sangat rendah. Perlakuan pemanasan pada temperatur tinggi dapat memutuskan ikatan hidrogen sehingga struktur kolagen menjadi tidak stabil dan mengalami denaturasi. Terjadinya denaturasi tersebut menyebabkan terjadinya penurunan viskositas kolagen.

\section{Suhu Denaturasi}

Salah satu sifat penting kolagen adalah stabilitas termal kolagen yang berkaitan langsung dengan suhu denaturasi kolagen. Suhu denaturasi menunjukkan ketahanan kolagen terhadap perlakuan suhu tertentu. Kolagen ikan mempunyai suhu denaturasi yang lebih rendah dibandingkan dengan kolagen mamalia. Kolagen babi misalnya, mempunyai suhu denaturasi sebesar $37^{\circ} \mathrm{C}$. Sedangkan sebagian besar kolagen ikan mempunyai suhu denaturasi di bawah $30^{\circ} \mathrm{C}$, dan dilaporkan bahwa jenis ikan yang mempunyai suhu denaturasi di atas $30^{\circ} \mathrm{C}$ sangat terbatas, seperti skipjack dan carp (Ogawa et al., 2004).

\section{Kandungan Asam Amino dari Kolagen}

Kolagen tersusun atas beberapa asam amino terutama glisin, prolin, dan hidroksiprolin. Glisin merupakan asam amino terbesar penyusun kolagen. Kolagen tidak mengandung triptofan dan sistein, dan sangat rendah tirosin dan histidin (Muyonga et al.,
2004). Kolagen ikan mempunyai jumlah hidroksiprolin dan stabilitas yang rendah dibandingkan dengan kolagen hewan vertebrata darat (Bailey \& Light, 1989). Kandungan hidroksiprolin tergantung pada jenis ikan, suhu tubuh, dan suhu lingkungan di mana ikan hidup (Rigby, 1968). Kolagen yang dihasilkan dari spesies ikan yang hidup di lingkungan dingin mempunyai kandungan hidroksiprolin yang lebih rendah dan menunjukkan stabilitas termal yang lebih rendah dari pada ikan yang hidup di lingkungan perairan panas. Hal ini dikarenakan hidroksiprolin mengandung ikatan hidrogen yang menstabilkan struktur triple helix molekul kolagen.

Berdasarkan penelitian Kittiphattanabawon et al. (2005) pada ikan bigeye snapper, asam amino dalam kolagen yang diperoleh dari kulit mempunyai kandungan yang sama dengan kolagen dari tulang, hanya saja komposisinya sedikit berbeda. Dibandingkan dengan kolagen yang berasal dari tulang, kolagen kulit mempunyai jumlah hidroksiprolin, prolin, dan arginin yang lebih tinggi, tetapi jumlah glisin dan hidroksisilin yang lebih rendah (Tabel 2).

\section{Mutu Kolagen}

Mutu kolagen ditentukan oleh beberapa hal seperti yang tercantum dalam Tabel 3.

\section{PEMANFAATAN KOLAGEN IKAN PADA INDUSTRI}

Saat ini, penggunaan kolagen pada industri telah meluas khususnya pada bidang medis, pangan, farmasi, dan kosmetik. Dalam bidang medis, kolagen dapat dikombinasikan dengan silikon, fibroblast, dan substansi lainnya, sehingga dapat digunakan sebagai kulit tiruan untuk mengatasi masalah kulit terbakar. Kolagen merupakan agen hemostatis yang sangat baik dan dapat mempercepat proses penyembuhan luka. Selain itu, kolagen juga digunakan dalam bedah cardiovascular, bedah plastik, ortopedik, urologi, neurologi, dan ophthalmology (Meena et al., 2009). 
Tabel 2. Komposisi asam amino dari kulit dan tulang bigeye snapper (residu/1000 residu)

\begin{tabular}{clcc}
\hline No & \multicolumn{1}{c}{ Asam amino } & Kulit & Tulang \\
\hline 1 & Asam aspartat & 51 & 47 \\
2 & Hidroksiprolin & 77 & 68 \\
3 & Treonin & 29 & 25 \\
4 & Serin & 36 & 34 \\
5 & Asam glutamat & 78 & 74 \\
6 & Prolin & 116 & 95 \\
7 & Glisin & 286 & 361 \\
8 & Alanin & 136 & 129 \\
9 & Valin & 22 & 17 \\
10 & Metionin & 12 & 8 \\
11 & Isoleusin & 5 & 5 \\
12 & Leusin & 24 & 25 \\
13 & Tirosin & 4 & 2 \\
14 & Fenilalanin & 15 & 12 \\
15 & Hidroksisilin & 10 & 20 \\
16 & Lisin & 31 & 25 \\
17 & Histidin & 10 & 6 \\
18 & Arginin & 60 & 46 \\
\hline & Total & 1000 & 1000 \\
\hline
\end{tabular}

Sumber: Kittiphattanabawon et al., 2005.

Tabel 3. Standar mutu kolagen

\begin{tabular}{clc}
\hline No & \multicolumn{1}{c}{ Kriteria } & Spesifikasi \\
\hline 1 & Kenampakan & Bubuk putih \\
2 & Bau & Tidak berbau \\
3 & Total protein (\%) & $>95$ \\
4 & $\mathrm{pH}$ & $5.5-6.5$ \\
5 & Kadar air (\%) & $<6.0$ \\
6 & Lemak (\%) & $<0.5$ \\
7 & Abu (\%) & $<2.0$ \\
8 & Logam berat (ppm) & $<20$ \\
9 & Berat molekul (Da) & 1000 \\
10 & Hydroxyproline & $>9.5$ \\
11 & Jumlah mikroba (koloni/g) & $<1000$ \\
12 & Coliform & Negatif \\
13 & Bakteri patogen & Negatif \\
\hline
\end{tabular}

Sumber: Anon., 2008. 
Dalam bidang pangan, kolagen dapat digunakan sebagai pembungkus makanan yang dapat dimakan (edible coating). Kolagen ikan dapat menggantikan penggunaan plastik sebagai bahan kemasan pada produk pangan. Proses pemanasan pada plastik dapat menghasilkan residu berbahaya yang dapat mengganggu kesehatan. Hal itu dikarenakan polimer plastik dapat terdegradasi menjadi monomer yang dapat menyebabkan penyakit kanker. Salah satu penggunaan edible kolagen yaitu sebagai pembungkus sosis, sehingga pembungkusnya dapat langsung dimakan. Sedangkan dalam bidang farmasi, kolagen dapat dikonversi menjadi gelatin yang merupakan bahan baku pembuatan kapsul.

Sementara itu, dalam bidang kosmetik, kolagen dapat diaplikasikan dalam bentuk masker wajah. Serat kolagen penting untuk menjaga elastisitas, kelembaban, dan kekencangan kulit. Walaupun jaringan kulit manusia mengandung $75 \%$ kolagen, namun kandungannya berkurang seiring dengan bertambahnya usia di mana kulit mengalami perubahan struktur, fungsi serta metabolik sehingga kulit menjadi kering dan tipis serta munculnya kerutan halus. Selain itu, paparan sinar UV yang berlebihan dapat menyebabkan terbentuknya radikal bebas dan munculnya enzim proteolitik. Enzim ini dapat memecah kolagen dan jaringan penghubung di bawah kulit dermis sehingga menyebabkan terjadinya kerusakan kulit. Selain sebagai masker, kolagen juga dapat digunakan sebagai bahan tambahan pada pembuatan produk perawatan rambut, wajah, dan tubuh seperti sampo, kondisioner, sabun, body lotion, dan kosmetik lainnya (Junianto et al., 2006).

Fungsi kolagen lainnya adalah sebagai bahan untuk melindungi tulang dan cairan sinovial supaya tidak terdeteriorasi dan juga sebagai bahan untuk pembentukan dan pemeliharaan tulang. Kolagen juga dapat berfungsi untuk mengurangi kerusakan akibat oksidasi, pelunakan, dan pengembangan terhadap kulit. Kolagen tidak toksik dan tidak mempunyai efek samping sehingga sangat baik digunakan dalam farmasi sebagai bahan non-steroid dan anti-inflamasi. Dengan demikian kolagen dapat meningkatkan ketahanan tubuh dari berbagai penyakit pusing, mual, sesak nafas, dan lupus (Nagai et al., 2004).

\section{PROSPEK LIMBAH PERIKANAN MENJADI KOLAGEN}

Indonesia memiliki potensi perikanan yang besar baik perikanan tangkap maupun budidaya. Produksi perikanan tangkap Indonesia pada tahun 2006 menduduki peringkat empat di dunia setelah Cina, Peru, dan Amerika, yaitu sebesar 4,77 juta ton. Produksi perikanan ini mengalami peningkatan sebesar $5,12 \%$ setiap tahunnya seperti yang terlihat pada Tabel 4 (Wahyuni \& Poernomo, 2008).

Meningkatnya produksi perikanan ini diikuti dengan berkembangnya industri pengolahan perikanan yang tersebar di Indonesia. Misalnya saja industri pengalengan ikan. Pada tahun 2005, terdapat 76 industri pengalengan ikan di Indonesia dalam skala sedang maupun besar (Tabel 5). Selain itu, dengan berlimbahnya bahan baku ikan pada beberapa daerah di Indonesia, maka industri pengalengan ikan diperkirakan akan semakin berkembang.

Dilaporkan bahwa terdapat 11 wilayah di Indonesia yang mempunyai potensi untuk mendirikan industri pengalengan ikan karena tersedianya bahan baku ikan seperti yang tercantum pada Tabel 6 .

Industri pengolahan ikan diketahui selalu menyisakan limbah dalam jumlah yang besar. Limbah tersebut diperkirakan memiliki proporsi $37,9 \%$ dari total bahan baku yang terdiri dari bagian kepala sekitar $12,0 \%$; tulang $11,7 \%$; sirip 3,4\%; kulit $4,0 \%$; duri $2,0 \%$; bagian isi perut sekitar $4,8 \%$ turut serta di dalamnya gelembung renang, hati, dan gonad. Besarnya jumlah limbah padat perikanan tergantung pada jenis ikan dan metode preparasinya. Tuna dan cakalang merupakan jenis ikan pelagis besar yang menyisakan limbah padat dalam jumlah yang cukup besar.

Tabel 4. Jumlah produksi perikanan tangkap Indonesia dari tahun 2002-2006

\begin{tabular}{cc}
\hline Tahun & Produksi perikanan (ton) \\
\hline 2002 & 4379055 \\
2003 & 4691814 \\
2004 & 4652684 \\
2005 & 4703927 \\
2006 & 4769150 \\
\hline
\end{tabular}

Sumber: (Fishstat FAO, 2008 dalam Wahyuni \& Poernomo, 2008). 
Tabel 5. Jumlah industri pengalengan ikan

\begin{tabular}{cccccccc}
\hline $\begin{array}{c}\text { Pengalengan } \\
\text { Ikan }\end{array}$ & \multicolumn{4}{c}{ Tahun } & \multicolumn{3}{c}{ Kenaikan rata-rata (\%) } \\
\cline { 2 - 8 } & $\mathbf{2 0 0 1}$ & $\mathbf{2 0 0 2}$ & $\mathbf{2 0 0 3}$ & $\mathbf{2 0 0 4}$ & $\mathbf{2 0 0 5}$ & $\mathbf{2 0 0 1 - 2 0 0 5}$ & $\mathbf{2 0 0 4 - 2 0 0 5}$ \\
\hline Skala sedang & 42 & 40 & 36 & 35 & 42 & 0.62 & 20.00 \\
Skala besar & 25 & 26 & 31 & 32 & 34 & 8.18 & 6.25 \\
\hline \multicolumn{1}{c}{ Total } & $\mathbf{6 7}$ & $\mathbf{6 6}$ & $\mathbf{6 7}$ & $\mathbf{6 7}$ & $\mathbf{7 6}$ & $\mathbf{3 . 3 6}$ & $\mathbf{1 3 . 4 3}$ \\
\hline
\end{tabular}

Sumber: (Statistik Industri Besar dan Sedang 2004-2006, BPS dalam Wahyuni \& Poernomo, 2008).

Tabel 6. Potensi industri pengalengan ikan di Indonesia

\begin{tabular}{rlr}
\hline No & \multicolumn{1}{c}{ Wilayah } & $\begin{array}{c}\text { Ketersediaan bahan } \\
\text { baku ikan (ton) }\end{array}$ \\
\hline 1 & Irian Jaya Barat & 84459 \\
2 & Sulawesi Utara & 192152 \\
3 & Jambi & 8296 \\
4 & Jawa Tengah & 236235 \\
5 & Nusa Tenggara Timur & 377390 \\
6 & Papua & 182789 \\
7 & Sulawesi Barat & 45211 \\
8 & Sulawesi Tengah & 44545 \\
9 & Sulawesi Tenggara & 166861 \\
10 & Sumatra Barat & 211821 \\
11 & Sumatera Selatan & 119853 \\
\hline
\end{tabular}

Sumber: Anon. (2009b).

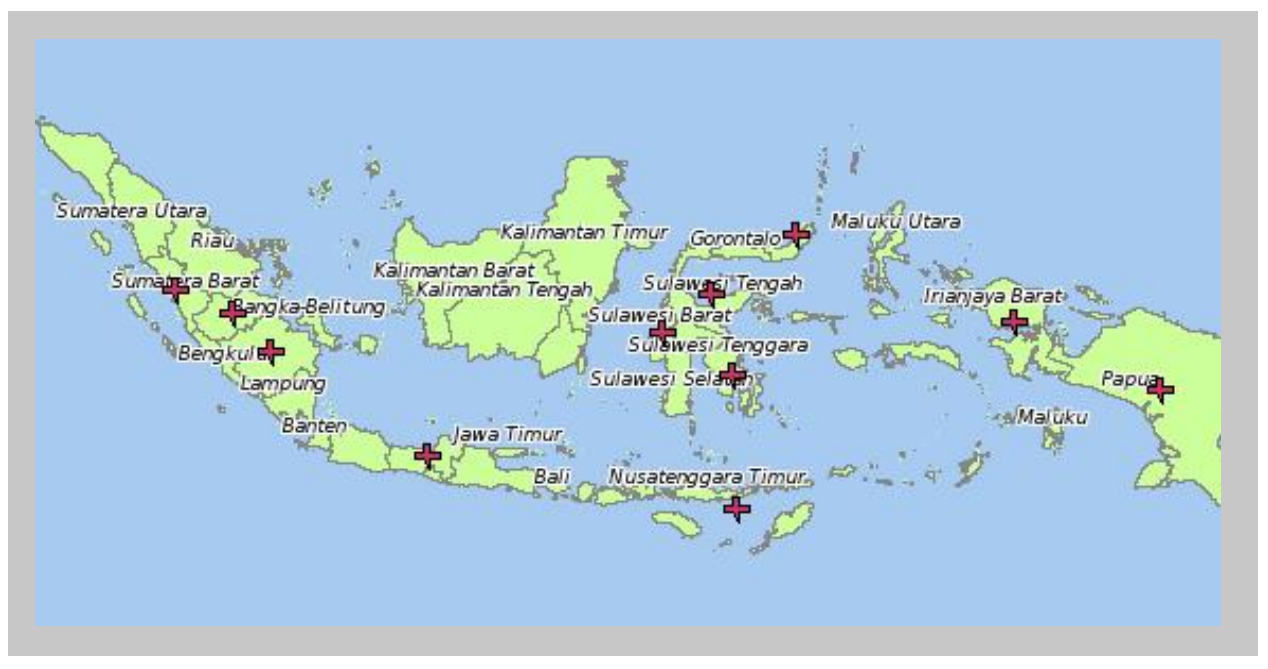

Gambar 5. Potensi industri pengalengan ikan di Indonesia (Anon., 2009b). 
Mengacu pada Tabel 4, jika dilihat jumlah produksi perikanan tangkap Indonesia tahun 2006, yaitu sebesar 4,77 juta ton, dapat diperkirakan bahwa limbah padat perikanan yang dihasilkan per tahunnya yaitu sekitar 1,81 juta ton dari total produksi ikan. Jika rendemen kolagen berkisar antara 11-63\%, maka limbah padat perikanan sebesar 1,81 juta ton dapat menghasilkan kolagen dalam jumlah yang besar, yaitu sekitar $0,2-1,14$ juta ton. Dengan berlimpahnya produksi kolagen yang berasal dari limbah perikanan di Indonesia, maka dapat diasumsikan bahwa limbah perikanan dapat menjadi sumber kolagen yang potensial untuk memenuhi kebutuhan kolagen dalam negeri maupun untuk ekspor. Industri kolagen dapat meningkatkan nilai tambah perikanan sehingga limbah perikanan tidak lagi menjadi hasil samping yang tidak berharga melainkan menjadi produk yang bernilai ekonomis tinggi.

\section{PENUTUP}

Limbah perikanan mengandung kolagen yang memiliki nilai ekonomis tinggi. Limbah perikanan ini menghasilkan kolagen dengan rendemen yang bervariasi antara 10,94-63,10\%. Nilai rendemen ini dipengaruhi oleh beberapa faktor, salah satunya adalah teknik ekstraksi kolagen. Ekstraksi kolagen dengan adanya penambahan pepsin dalam larutan asam memberikan nilai rendemen yang lebih tinggi bila dibandingkan dengan ekstraksi menggunakan larutan asam tanpa pepsin. Selain itu, kolagen yang diperoleh mempunyai karakteristik yang berbeda, salah satunya adalah kelarutan. PSC (Pepsin Soluble Collagen) mempunyai kelarutan yang lebih tinggi dibandingkan ASC (Acid Soluble Collagen). Dengan diperolehnya nilai rendemen kolagen ikan yang tinggi dengan karakteristik yang baik, maka diharapkan bahwa limbah perikanan dapat menjadi sumber kolagen untuk memenuhi kebutuhan industri medis, pangan, farmasi, dan kosmetik. Di Indonesia, diperkirakan terdapat limbah perikanan sebesar 1,77 juta ton per tahun dari total produksi perikanan tangkap Indonesia tahun 2006 sebesar 4,77 juta ton, sehingga diperoleh kolagen sebesar 0,2-1,14 juta ton. Dengan demikian, limbah perikanan berpotensi menjadi sumber kolagen yang potensial.

\section{DAFTAR PUSTAKA}

Anonim. 2009a. Kolagen. http://www.wikipedia.org/wiki/ kolagen. Diakses pada tanggal 20 Juli 2009.

Anonim. 2009b. Industri pengalengan ikan. http:// regionalinvestment.com/sipid/id/commodity.php. Diakses pada tanggal 22 November 2009.

Anonymous. 2000. Collagen. http://www.pdb.org/pdb/ static. Accessed on November 22, 2009.
Anonymous. 2008. Hydrolyzed fish collagen. http:// www.ecvv.com/product/1212198.html. Accessed on November 26, 2009.

Apriantoro, E.W. 2007. Isolasi dan Karakterisasi Kolagen dari Kulit Ikan Kerapu Lumpur (Epinephelus tauvina) Sebagai Bahan Baku Farmasi. Skripsi. Fakultas MIPA, Univeritas Indonesia, 115 pp.

Baily, A.J. and Light, N.D. 1989. Genes, Biosynthesis and Degradation of Collagenin Connetive Tissue in Meat and Meat Products. London: Elsevier. $355 \mathrm{pp}$.

DeMan, J.M. 1989. Kimia Makanan. Edisi Kedua. Penerjemah Padmawinata K. ITB Press, Bandung. $550 \mathrm{pp}$.

Jongjareonrak, A., Benjakul, S., Visessanguan, W., and Tanaka, M. 2005. Isolation and characterization of collagen from bigeye snapper (Priacanthus macracanthus) skin. Journal of the Science of Food and Agriculture. 85: 1203-1210.

Junianto, Haetami, K., dan Maulina, I. 2006. Produksi Gelatin dari Tulang Ikan dan Pemanfaatannya sebagai Bahan Dasar Pembuatan Cangkang Kapsul. Laporan penelitian hibah bersaing IV Tahun I. Fakultas Perikanan dan IImu Kelautan Universitas Padjadjaran.

Kittiphattanabawon, P., Benjakul, S., Visessaguan, W., Nagai, T., and Tanaka, M. 2005. Characterization of acid-soluble collagen from skin and bone of bigeye snapper (Priacanthus tayenus). Food Chem. 89: 363 -372 .

Lestari, T. 2007. Isolasi dan Karakterisasi Kolagen dari Tulang Ikan Tuna (Thunnus albacares) Sebagai Bahan Baku Industri Farmasi. Skripsi. Fakultas MIPA, Universitas Indonesia, $83 \mathrm{pp}$.

Meena, C., Mengi, S.A., and Deshpande, S.G. 2009. Biomedical and industrial applications of collagen. Chemical Sciences. 111: 319-329.

Muyonga, J.H., Cole, C.G.B., and Duodu, K.G. 2004. Characterization of acid soluble collagen from skins of young and adult Nile Perch (Lates niloticus). Food Chem. 85: 81-89.

Nagai, T. and Suzuki, N. 2000. Isolation of collagen from fish waste material-skin, bone, and fins. Food Chem. 68: 277-281.

Nagai, T., Yamashita, E., Taniguchi, K., Kanamori, N., and Suzuki, N. 2001. Isolation and characterization of collagen from the outer skin waste material of cuttle fish (Sepia lycidas). Food Chem. 72: 524-429.

Nagai, T., Araki, Y., and Suzuki, N. 2002. Collagen of the skin of occellate puffer fish (Takifugu rubripes). Food Chem. 78: 173-177.

Nagai, T., Izumi, M., and Ishii,M. 2004. Fish scale collagen. Preparation and partial characterization. International Journal of Food Science and Technology. 39 (3): 239-244.

Noitup, P., Garnjanagoonchorn, W., and Morrissey, M.T. 2005. Fish skin type I collagen: characteristic comparison of albacore tuna (Thunnus alalunga) and silver-line grunt (Pomadasys kaakan). Journal of Aquatic Food Product Technology. 14: 17-27. 
Ogawa, M., Portier, R.J., Moody, M.W., Bell, J., Schexnayder, M.A., and Losso, J.N. 2004. Biochemical properties of bone and scales collagen isolated from the subtropical fish black drum (Pogonia cromis) and sheepshead seabream (Archosargus probatocephalus). Food Chem. 88: 495-501.

Peranginangin, R., Ma'ruf, W.F., Tazwir, Hak, N., Suryanti, Ayudiarti, D.L., Maraskuranto, E., dan Haryanto. 2005. Riset optimasi pemanfaatan limbah perikanan tulang dan kulit ikan. Laporan Teknis Penelitian Pengolahan Produk. Balai Besar Riset Pengolahan
Produk dan Bioteknologi Kelautan dan Perikanan. Jakarta.

Rigby, B.J. 1968. Amino acid composition and thermal stability of the skin collagen of the Antartic ice fish. Nature. 219: 166-167.

Senaratne, L.S., Park, P.J., and Kim, S.K. 2005. Isolation and characterization of collagen from brown backed toadfish (Lagocephalus gloveri) skin. Bioresource Technology. 97: 191-197.

Wahyuni, M. dan Poernomo, S.H. 2008. Kelautan dan Perikanan Dalam Angka. Departemen Kelautan dan Perikanan. Jakarta, $93 \mathrm{pp}$. 